\title{
Elderly male patient with unilateral proptosis and decreased vision of the left eye
}

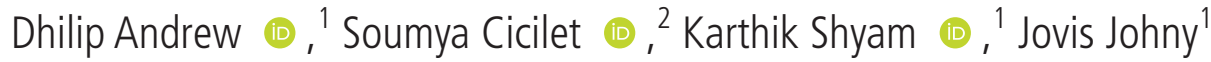

${ }^{1}$ Radiology, St John's Medical College Hospital, Bangalore, Karnataka, India

${ }^{2}$ Department of Radiodiagnosis, St John's Medical College Hospital, Bangalore, Karnataka, India

\section{Correspondence to}

Dr Karthik Shyam;

dr.karthikshyam@gmail.com

Accepted 18 September 2020

Check for updates

(C) BMJ Publishing Group Limited 2020. No commercial re-use. See rights and permissions. Published by BMJ.

To cite: Andrew D, Cicilet $\mathrm{S}$, Shyam K, et al. BMJ Case Rep 2020;13:e239285. doi:10.1136/bcr-2020239285

\section{DESCRIPTION}

A 71-year-old hypertensive man presented to ophthalmology with proptosis of the left eye for 2-month duration with gradually diminishing vision. On examination, the left eye proptosis with chemosis was seen, with exposure keratitis and lid oedema. Perception of light was the visual acuity of the left eye, with sluggish pupillary reactivity. The right eye visual acuity was normal.

Contrast-enhanced MR of orbits demonstrated an enhancing T1 hypo-hyperintense/T2 iso-hyperintense intraconal lesion, indenting the optic nerve (figure 1E), lamina papyracea and left globe. Extension into the middle cranial fossa (figure $1 \mathrm{~A}-\mathrm{D}, \mathrm{F}, \mathrm{H}$ ) through the superior orbital fissure was seen with involvement of left cavernous sinus (figure $1 \mathrm{G}$ ). Non-enhanced CT scan demonstrated intraorbital soft-tissue mass causing scalloping and widening of orbital walls, superior orbital fissure, greater wing of sphenoid and anterior clinoid process (figure $2 \mathrm{~A}-\mathrm{H}$ ). Imaging diagnosis of soft-tissue sarcoma was raised. The patient underwent enucleation of the left eye with craniotomy-excision of the intracranial component. The histopathological and immunohistochemical diagnosis was low-grade myxofibrosarcoma (MFS).

MFS is of fibroblastic origin with myoid matrix, it commonly involves the extremities in elderly individuals, though incidence in the young is reported. ${ }^{1-4}$ Orbital MFS is rare, probably owing to the everchanging definition of the tumour, ${ }^{5}$ with possible misdiagnosis as malignant fibrous histiocytoma. ${ }^{6}$ MFS is classified into three grades, with grades II and III showing metastatic potential, and grade I being locally aggressive. ${ }^{3}$ MFS is usually present as painless, enlarging mass. ${ }^{4}$ Orbital MFS can present with proptosis, diplopia, eyelid swelling, altered visual acuity and orbital motility. ${ }^{4-8}$

On CT scan, MFS appears isodense to extraocular muscles, ${ }^{8}$ with hyperdensity corresponding to areas of hypercellularity. ${ }^{9}$ On MR, the lesion is isointense on T1 weighted, hyperintense on T2 weighted to extraocular muscles. ${ }^{7}$ Hypercellular areas are hyperintense on T1 weighted and hypointense on T2 weighted. ${ }^{9}$ On contrast-enhanced CT scan and MR, areas with increased cellularity show homogeneous contrast uptake. Hypercellularity indicates tumour grade progression. ${ }^{9}$ For reliable identification of the subtype of sarcoma, immunohistochemical and cytomorphological findings are important. ${ }^{10}$ Histological findings include spindle or stellate-shaped fibroblasts within a myxoid stroma, with hyperchromatic tumour cells showing moderate-to-marked pleomorphism. ${ }^{2} 3$ On immunohistochemical staining, positivity for vimentin is seen, indicating fibroblastic differentiation. ${ }^{4}$

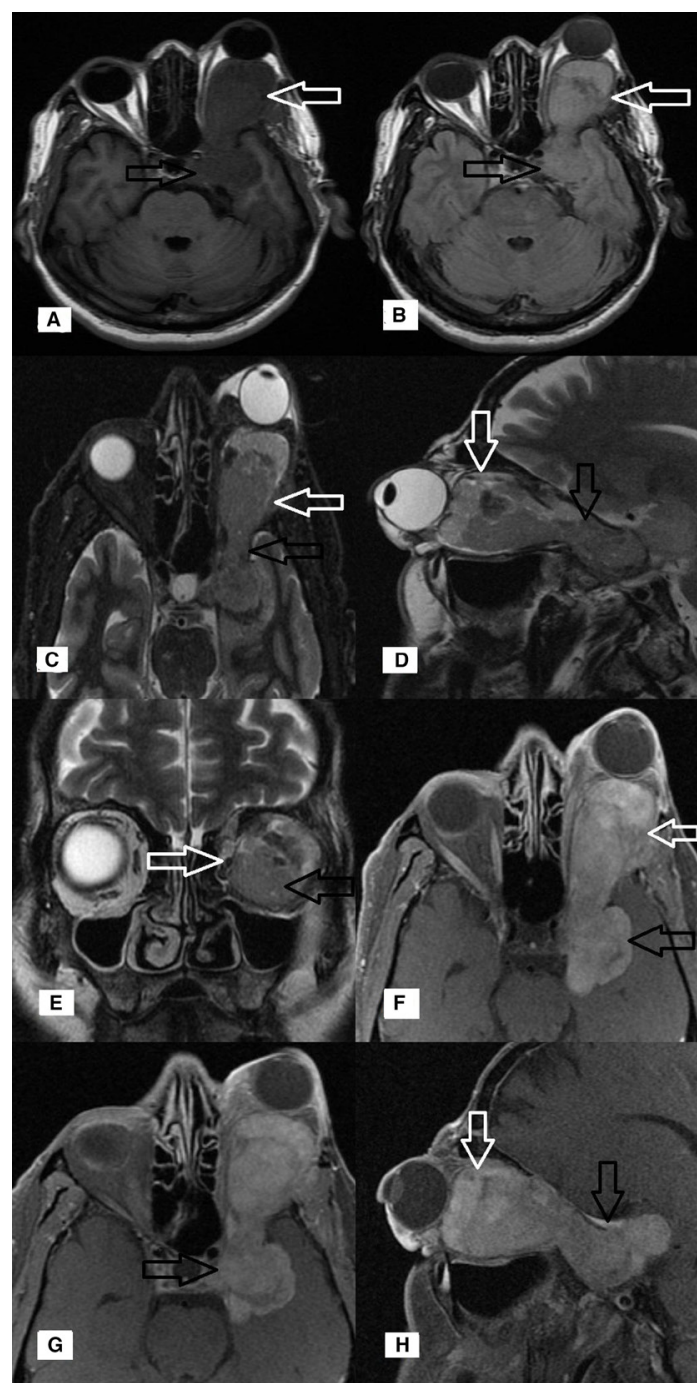

Figure 1 (A, B) Plain T2 and T1 Fluid Attenuation Inversion Recovery axial images demonstrating T2/T1 isointense lesion (white arrow) within left orbit with extension (black arrow) into middle cranial fossa with features of proptosis. (C, D) Axial Short Tau Inversion Recovery and T2 Fast Spin Echo images demonstrating the orbital mass (white arrow) with local extension (black arrow) via orbital fissure. (E) Coronal T2 image demonstrating orbital mass (black arrow) separate from optic nerve (white arrow). (F, H) Postcontrast axial and sagittal T1 images demonstrating enhancing orbital mass lesion (white arrow) with feature of intracranial extension (black arrow). (G) Postcontrast axial T1 image demonstrating involvement of the left cavernous sinus (white arrow). 


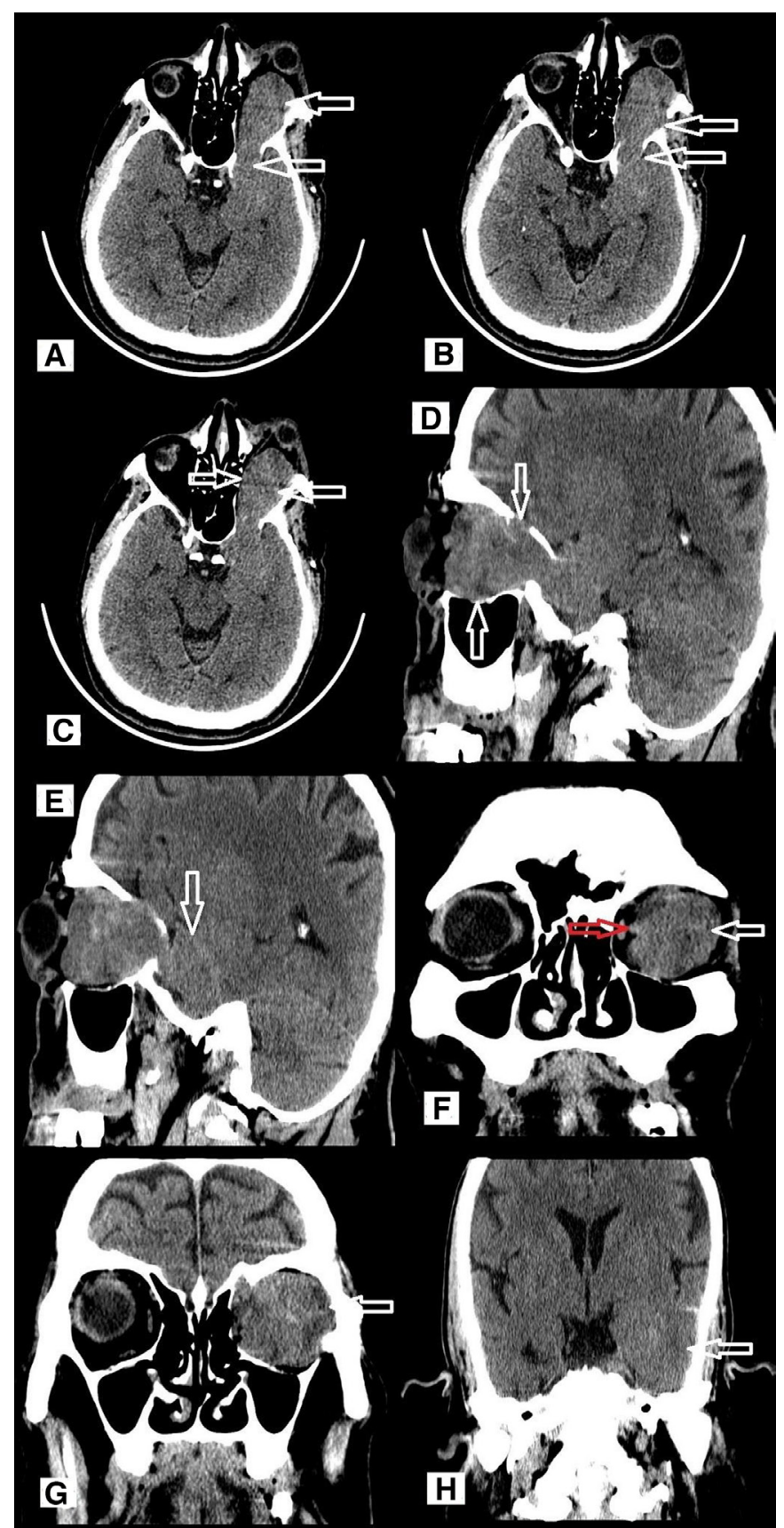

Figure 2 (A-C) Non-contrast CT axial image demonstrating softtissue density mass (white arrow) within left orbit, extending via orbital fissure into middle cranial fossa. (D) Sagittal non-contrast CT images demonstrate soft-tissue density mass causing erosion of bony orbit (white arrow). (E, F) Sagittal and coronal non-contrast images demonstrate orbital mass extending (white arrow) into middle cranial fossa and separate from optic nerve (red arrow). (G, H) Coronal non-CT images demonstrating orbital mass with local extension.

Low-grade MFS of the extremities is managed by wide local excision (WLE) with radiotherapy, in view of possible local recurrence. ${ }^{11}$ For orbital low-grade MFS, adjuvant radiotherapy would be more relevant since WLE may not be possible. However, high-grade tumours are refractory to non-surgical management. ${ }^{312} 13$ MFS has a $60 \%$ recurrence rate irrespective of tumour grade. ${ }^{12}$ Lungs are usually the primary site of metastasis. ${ }^{9}$ Low-grade tumours have lower metastatic potential. ${ }^{1-3} 12$ Histopathological findings of size
$(>5 \mathrm{~cm})$, myxoid proportion $(<75 \%$ of stroma), mitotic index $(>20 / 10 \mathrm{HPF})$ and tumour necrosis $(>10 \%)$ help predict metastatic relapse. ${ }^{1214}$ Careful radiological examination combined with histopathological and immunohistochemical examination of lesion are required for accurate diagnosis and prognostication.

\section{Learning points}

- Low-grade myxofibrosarcoma (MFS) is a underdiagnosed entity and can be misreported as malignant fibrous histiocytoma.

- MFS is a mesenchymal tumour of the elderly and usually occurs in the extremity. MFS of orbit is very rare.

- MRI and CT scan can identify areas of increased cellularity and vascularity. Histopathological and immunohistochemical examination is required to identify the subtype and prognosticate.

Contributors DA, SC, KS and JJ have equally contributed to procurement of images, interpretation and clinical follow-up. DA drafted the manuscript, SC, KS and JJ have edited and finalised the draft.

Funding The authors have not declared a specific grant for this research from any funding agency in the public, commercial or not-for-profit sectors.

Competing interests None declared.

Patient consent for publication Obtained.

Provenance and peer review Not commissioned; externally peer reviewed.

\section{ORCID iDs}

Dhilip Andrew http://orcid.org/0000-0002-6154-3063

Soumya Cicilet http://orcid.org/0000-0003-1311-9601

Karthik Shyam http://orcid.org/0000-0003-0998-9604

\section{REFERENCES}

1 Angervall L, Kindblom LG, Myxofibrosarcoma MC. A study of 30 cases. Acta Pathol Microbiol Scand [A] 1977;85A:127-40.

2 Merck C, Angervall L, Kindblom LG, et al. Myxofibrosarcoma. A malignant soft tissue tumor of fibroblastic-histiocytic origin. A clinicopathologic and prognostic study of 110 cases using multivariate analysis. Acta Pathol Microbiol Immunol Scand Suppl 1983;282:1-40.

3 Mentzel T, Calonje E, Wadden C, et al. Myxofibrosarcoma. clinicopathologic analysis of 75 cases with emphasis on the low-grade variant. Am J Surg Pathol 1996;20:391-405.

4 Zhang Q, Wojno TH, Yaffe BM, et al. Myxofibrosarcoma of the orbit: a clinicopathologic case report. Ophthalmic Plast Reconstr Surg 2010;26:129-31.

5 Clair BC, Salloum G, Carruth BP, et al. Orbital myxofibrosarcoma: case report and review of literature. Ophthalmic Plast Reconstr Surg 2018;34:e180-2.

6 Wang M, Khurana RN, Parikh JG, et al. Myxofibrosarcoma of the orbit: an underrecognized entity? Ophthalmology 2008;115:1237-40.

7 Gire J, Weinbreck N, Labrousse F, et al. Myxofibrosarcoma of the orbit: case report and review of literature. Ophthalmic Plast Reconstr Surg 2012;28:e9-11.

8 Pujari A, Ali MJ, Honavar SG, et al. Orbital myxofibrosarcoma: a clinicopathologic correlation of an extremely rare tumor. Ophthalmic Plast Reconstr Surg 2014;30:e111-3

9 Meel R, Lokdarshi G, Kashyap S, et al. Giant myxofibrosarcoma of the orbit: a rare case and a review of the literature. BMJ Case Rep 2016;2016. doi:10.1136/bcr-2015214107. [Epub ahead of print: 13 Jun 2016].

10 Mitsuhashi T, Barr RJ, Machtinger LA, et al. Primary cutaneous myxofibrosarcoma mimicking pleomorphic hyalinizing angiectatic tumor (PhAT): a potential diagnostic pitfall. Am J Dermatopathol 2005;27:322-6.

11 Dewan V, Darbyshire A, Sumathi V, et al. Prognostic and survival factors in myxofibrosarcomas. Sarcoma 2012;2012:1-5.

12 Huang H-Y, Lal P, Qin J, et al. Low-Grade myxofibrosarcoma: a clinicopathologic analysis of 49 cases treated at a single institution with simultaneous assessment of the efficacy of 3-tier and 4-tier grading systems. Hum Pathol 2004;35:612-21.

13 Sanfilippo R, Miceli R, Grosso F, et al. Myxofibrosarcoma: prognostic factors and survival in a series of patients treated at a single institution. Ann Surg Oncol 2011;18:720-5.

14 Lin C-N, Chou S-C, Li C-F, et al. Prognostic factors of myxofibrosarcomas: implications of margin status, tumor necrosis, and mitotic rate on survival. J Surg Oncol 2006;93:294-303. 
Copyright 2020 BMJ Publishing Group. All rights reserved. For permission to reuse any of this content visit https://www.bmj.com/company/products-services/rights-and-licensing/permissions/

BMJ Case Report Fellows may re-use this article for personal use and teaching without any further permission.

Become a Fellow of BMJ Case Reports today and you can:

- Submit as many cases as you like

- Enjoy fast sympathetic peer review and rapid publication of accepted articles

Access all the published articles

Re-use any of the published material for personal use and teaching without further permission

Customer Service

If you have any further queries about your subscription, please contact our customer services team on +44 (0) 2071111105 or via email at support@bmj.com.

Visit casereports.bmj.com for more articles like this and to become a Fellow 